\title{
A REVIEW OF SPEECH THERAPY SERVICES IN TEN CEREBRAL PALSY SCHOOLS IN THE REPUBLIC OF SOUTH AFRICA
}

\author{
AUDREY SHAVELL, B.A. LOGOPEDICS (WITWATERSRAND) \\ Senior Speech Therapist, Forest Town Cerebral Palsy School, \\ Forest Town, Johannesburg
}

\begin{abstract}
SUMMARY
Information on speech therapy services at ten Cerebral Palsy Schools in South Africa was obtained by means of a questionnaire. The results compared the numbers of children receiving treatment on an-out-patient and in-paticnt basis; the percentage of children diagnosed as Cerebral Palsied, Minimal I3rain Dysfunction, A phasic: and unclassified in each school; the percentage of specch. voice, hearing and language disturbances in each diagnostic category, the frequency of speech therapy treatments and types of assessments used: The speech therapists who completed the questionnaire also gave their opinion on the valuc of joint assessments, case conferences and use of a communication board as well as topics they would like to discuss.
\end{abstract}

\section{OPSOMMING}

Deurmiddel van 'n vraelys, is inligting van spraakterapeute verkry aangaande dienste gelewer by skole vir serebraal-verlamde kinders. Die resultate vergelyk o.a.; aantal kinders wat behandeling as binne- of buitepasiënte, ontvang; die persentasie gediagnosecr as screbraal-verlam, minimaal breinbeseerd, afaties of nie-geklassifiseerd, by elke skool; die aantal met spraak-stem-gehoor en taalgebreke in elke diagnostiese afdeling; hoe dikwels elke kind behandeling ontvang; diagnostiese middels gebruik by elke afsonderlike skool. Bogenoemde spraakterapeute is ook gevra om hulle mening uit te spreek oor sckere aspekte van behandeling, d.i. die waarde van gesamentlike ondersoek, gevalle besprekings, die waarde van 'n kommunikasiebord, en ook onderwerpe van belang wat hulle graag sou wou bespreek.

Prior to 1948 no organized facilities for the treatment of the cerebral palsied existed in South Africa. In 1948, a small group of anxious parents formed an association called the Transvaal Association for the Care of the Cerebral Palsied (T.A.C.C.P.) to provide treatment and some form of education for their cerebral palsied children. This association opened the Forest Town Cerebral Palsy School in Johannesburg in January 1949, under the principalship of Mrs Elaine Clemons, a speech therapist and wife of the late Alan Clemons, Lecturer in Logopedics at the University of the Witwatersrand. The original enrolment of the school was eleven pupils and the staff consisted of one speech therapist, one physiotherapist and one aid. The school was entirely supported at first by the T.A.C.C.P. from unsolicited donations and a small municipal grant from the Johannesburg City Council. After the T.A.C.C.P. became a registered welfare organization public appeals for funds were made and later annual grants from the Transvaal Education Dept., assisted in main- 
taining the school until 1954.' In October 1955 the Special Education Act was passed by Parliament and the Forest Town Cerebral Palsy School, the Pretoria Cerebral Palsy School and the Vista Nova Cerebral Palsy School in Cape Town became state aided, retrospective from Ist $\Lambda$ pril 1954, under the Department of Education, Arts and Science. Approximately $90 \%$ of the total costs are subsidized by the Department of National Education, the body which presently controls education for all types of handicapped children in the Republic of Soutl Africa.

In 1955, the Cerebral Palsy Division of the National Council for the Care of Cripples in South Africa was established. The regional associations, organizations. schools, homes and training centres catering for the cerebral palsied affiliated to the Cerebral Palsy Division of the National Council for the Care of Cripples. The formation of the Cerebral Palsy Division provided the impetus for the establishment of further sclools, training and employment centres. The ten schools from which the data for this study were collected are all represented on the Cerebral Palsy Division of the National Council for the Care of Cripples in South Africa.

\section{METHOD}

Speech therapists working at the following schools completed a questionnaire in 1973.

(1) The Forest Town School for Cerebral Palsied Children, Johannesburg;

(2) The Pretoria School for Cerebral Palsied Children;

(3) The Vista Nova Cerebral Palsy School, Cape Town;

(4) The Cape Receife School for Cerebral Palsied, Port Elizabeth;

(5) The Brown's School for Cerebral Palsied, Pinetown, Natal;

(6) The West Rand School for Cerebral Palsied Children, Krugersdorp;

(7) The Muriel Brand School for Cerebral Palsied, State Mines, Transvaal;

(8) The Martie du Plessis School for Cerebral Palsied, Bloemfontein;

(9) The Frances Vorwerg School for Cerebral Palsied Children, Johannesburg;

(10) The New Hope School for Cerebral Palsied Children, Pretoria.

The questionnaire was designed to obtain some comparable data on the total enrolment at each school; number of patients receiving in-patient treatment and schooling: number of patients receiving out-patient treatment; the percentage of clildren diagnosed as Cerebral Palsied, Minimal Brain Dysfunction, Aphasic or unclassified in each school; the percentage of children lạing speech, voice, hearing or language problems, in each diagnostic category; the number of children receiving speech therapy in each school and the frequency of speech therapy treatments; the number of children not receiving speech therapy because of staff shortages; the different forms of assessment used in each school; the opinions of the speech therapists working in the cerebral palsy schools on the value of joint assessment of patients, on case conferences, on the use of a communication board or other similar non-vocal system of communication and the topics they would like to discuss if it were possible for speech therapists attached to cerebral palsy schools to meet. 
The schools are situated in different towns or cities and have been opened for between two and twenty-five years so it is not possible to make direct comparisons between the different schools in terms of size of total enrolment and percentages of in and out-patients. It is interesting to note that the school which has the highest out-patient attendance is also a training centre for medical and para-medical students of the University of the Witwatersrand, students of Goudstadse Onderwyskollege, Pretoria College of Occupational Therapy, the B.G. Alexander Nursing College and ștudent social workers. The results of this wide dissemination of knowledge can be seen in the increasing number of early referrals, not only of the physically disabled but also of children with learning difficulties, serious language disorders, and suspected minimal brain dysfunction, as well as 'al risk' babies who are referred for developmental observation. Babies have been referred, in the last category i.e. for developmental observation from the age of six weeks.

The majority 'of out-patients in all the schools are children below the age of three, which is the official age of admission in the cerebral palsy schools. The remainder are children attending normal schools or those who do not attend any school but come to a cerebral palsy school for one or more of the therapies. Due to lack of adequate alternate facilities, children who have 'soft neurological signs', learning disabilities and serious language disorders are admitted to the cerebral palsy schools if it is felt that they will benefit from the school facilities. The percentages of these children at each of the schools can be seen under the Minimal Brain Dysfunction and $A$ phasic Categories in the following tables.

\section{RESULTS}

One thousand, five hundred and fourteen children were receiving treatment and/or education at the time this survey was undertaken, $85,73 \%$ on an inpatient basis and $14,3 \%$ on an out-patient basis. Considering the four major diagnostic categories $56,19 \%$ were classified cerebral palsied, $34,66 \%$ as minimal brain dysfunction, 3,90\% as aphasic and 5,03\% as unclassified.

The definition of Cerebral Palsy was the one formulated in the Educational Services Act, 1967 (Act 41 of 1967 as amended) ${ }^{1}$ :

Criteria for the admission of pupils to schools for the Cerebral PalsiedCerebral Palsied children means children with disturbed function caused by a defect of or damage to the brain tissue, whose chief problem is not however, that of mental retardation. The defect may be localised or diffuse, and may occur before, during or at any time after the birth of the child. Where organic brain damage is the cause of neuro-motor, perceptual, or communication deviations, these defects may be present singly or in combination. Aphasic children are included if they are able to fit into the organization of the school, and if they can benefit from the education which is provided for cerebral palsied children. The children must be educable. The children's main problem is Cerebral Palsy (or Aphasia) and not any of the other handicaps listed in Schedule I in the Act. 


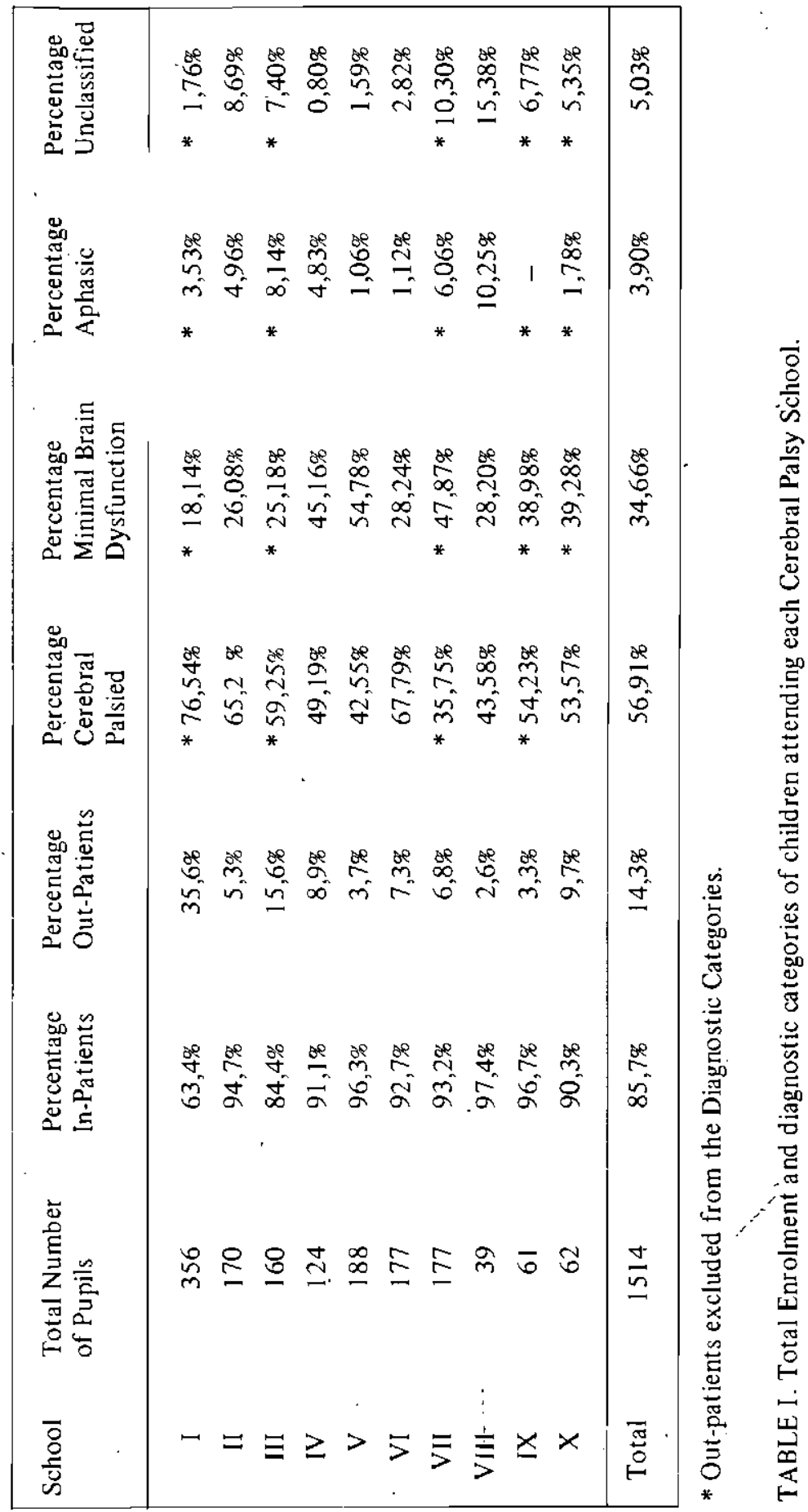

Journal of the Soult African Speech and Hearing Association. Vol, 21, December 1974 
Aphasia, is not defined in the act, but Eisenson's ${ }^{3}$ recent definition probably covers the children in this category at the various Cerebral Palsy Schools.

We shall be using the term developmental Aphasia to refer to the impairment for a child to acquire symbols for a langrage system. The impairment must be of sufficient degree to interfere with the child's ability to communicate. The use of the term developmental aphasia, or one of its synonyms, implies that the child's perceptual abilities for auditory (speech) events underlies this impairment for the acquisition of auditory symbols. His expressive disturbances are a manifestation of his intake or decoding impairment. A child cannot produce language if he cannot decode the speech to which he is exposed, or if the speech remains for him sounds without sense.

The definition of minimal brain dysfunction was that formulated by l'rofessor C.H. de C. Murray and his Committee of Inquiry into the Education of children with Minimal Brain Dysfunction: ${ }^{9}$

Children with Minimal Brain Dysfunction have anerage or above average intellectual ability, and the motor function, vision, hearing and cmotional adiustment are adequate, but they manifest specific learning disabilities or behavioural disabilities which are associated with deviations of the functioning of the central nervous system. Dysfunction of the central nervous system manifests itself in different ways and in various combinations of the deviations mentioned below: impairment namely of perception, conceptualisation, language, memory, control of attention, impulse and motor function.

In a recent survey Murray ${ }^{7}$ found that in practice all the Cerebral Palsy schools are admitting children with minimal brain dysfunction and subnormal intelligence in addition to those with average and above average intelligence.

The unclassified group included children with one of the undermentioned diagnosis:-

Spinabifida, lymphangioma, pituitary dwarfism, tumour, progressive cerebrocerebellar deterioration, cerebral damage and microcephaly, Freidrich's Ataxia, muscular dystrophy, hydrocephalus, epilepsy, crit-du-chat syndrome, congenital developmental anomalies, Lesch-Niehan Syndrome, await ing diagnoses.

Table Il shows a comparison between the number of pupils and number of speech therapists working at each school; the number and percentage of children with speech, voice, hearing and language problems in each school; the percentage of children receiving speech therapy; the percentage of children not receiving speech therapy in each school because of a shortage of speech therapists, and the percentage of speech, voice, hearing and language problems in each diagnostic category in each school.

Eight hundred and fifty-one, or 56,2\% of the one thousand, five hundred and fourteen children enrolled at the ten Cerebral Palsy schools at the time of this survey had speech, voice, hearing or language problems. $72,26 \%$ of the 851 


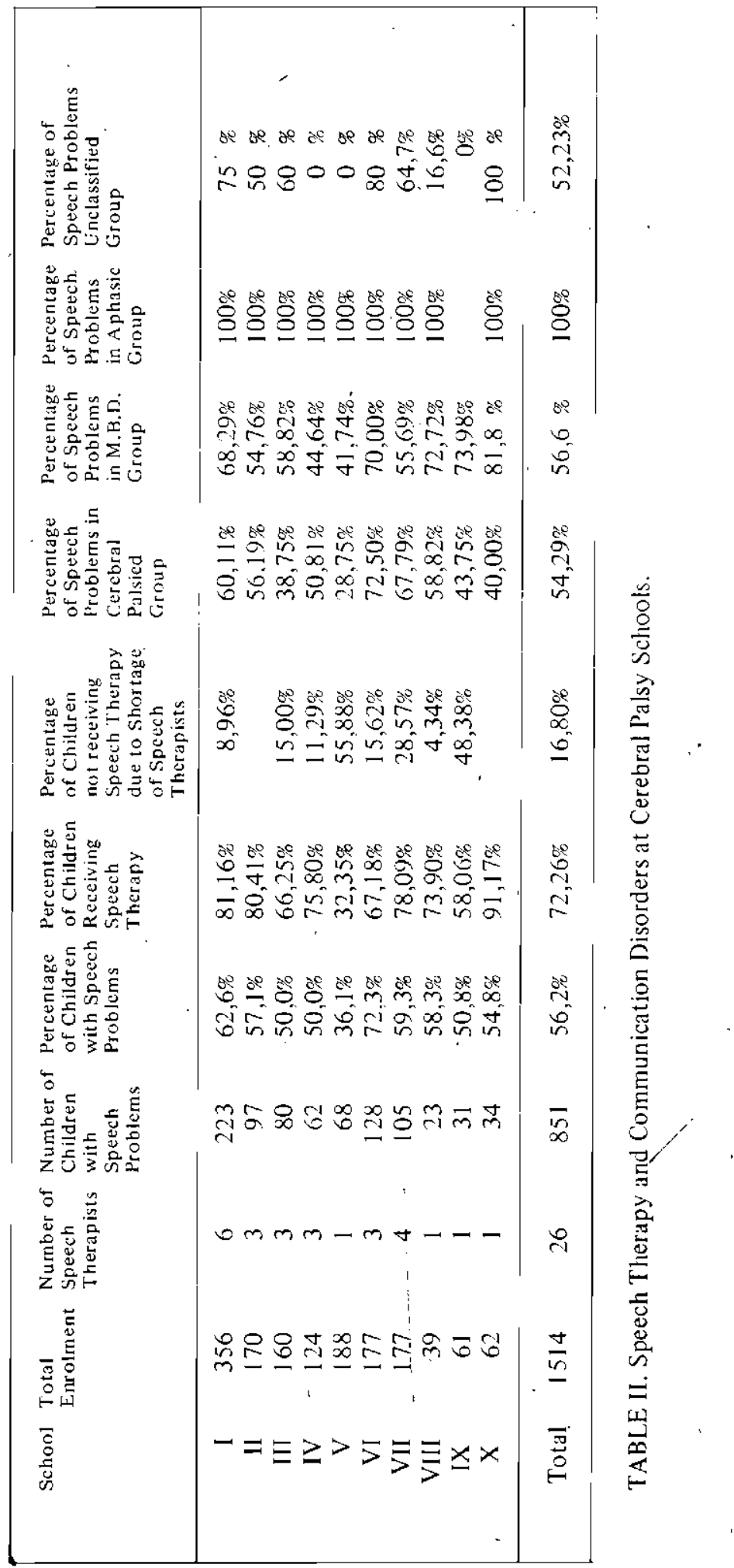


children nceding speech thcrapy reccived treatment and 16,80\% who needed speech therapy were not receiving treatment because of a shortage of speech therapists at the various schools. In answering the questionnaire the speech therapists at two schools commented that they felt patients would benefit from morc intensive therapy if more staff were available (Schools II and X). This question of the frequency of treatment is a very worrying one facing speech therapists at cerebral palsy schools. Should we try and spread our efforts among as many children as possible, seeing most patients once or twice weekly or should we treat less patients more intensively depending on their needs? After twenty ycars in this field the writer believes that three times weekly is the minimum and that best results are achieved with daily therapy or therapy four times a week. Most of the children with serious language problems and/or severe physical disabilitics require daily treatment to retain and reinforce what they have learned. Neurologically impaired children have notoriously poor memory spans; increasing the frequency of treatment increases the success ratio. There are also children at all the cerebral palsy schools whose speech therapy has been stopped although they have not achieved their maximum potential, because more urgent cases must also be given a chance. In a recent study done at the West Rand Cerebral Palsy School ${ }^{8}$ it was found that taking these children aga in for an intensive period of therapy, after termination of speech therapy, led to further improvement.

Increasing the number of speech therapy posts at cerebral palsy schools would relieve the tremendous pressure conscientious therapists labour under and would give these children a chance to function more adequately in society. We should remember that it is through speech more surely than through any other form of expression that the majority of cerebral palsied children may be given the opportunity to reveal their intelligence, their personality and their character.

Three hundred and thirty-six, or 54,63\% of the six hundred and fifteen children under treatment at the time of this survey were receiving speech therapy twice a week or. less than twice a. week. If one accepts that ad equate speech therapy means three or more scssions a week, half of the group were receiving insufficient treatment. In fact if we cxamine the percentage of the schools separately we see that in five of the ten schools more than $50 \%$ wcre not receiving sufficient speech therapy. These were:-

School I $64,64 \%$ receiving less than 3 treatments per week

School II 82,05\% receiving less than 3 treatments per week

School VI $54,65 \%$ receiving less than 3 treatments per wcck

School IX 50,00\% receiving less than 3 treatments per week

School X 74,19\% receiving less than 3 treatments per week 


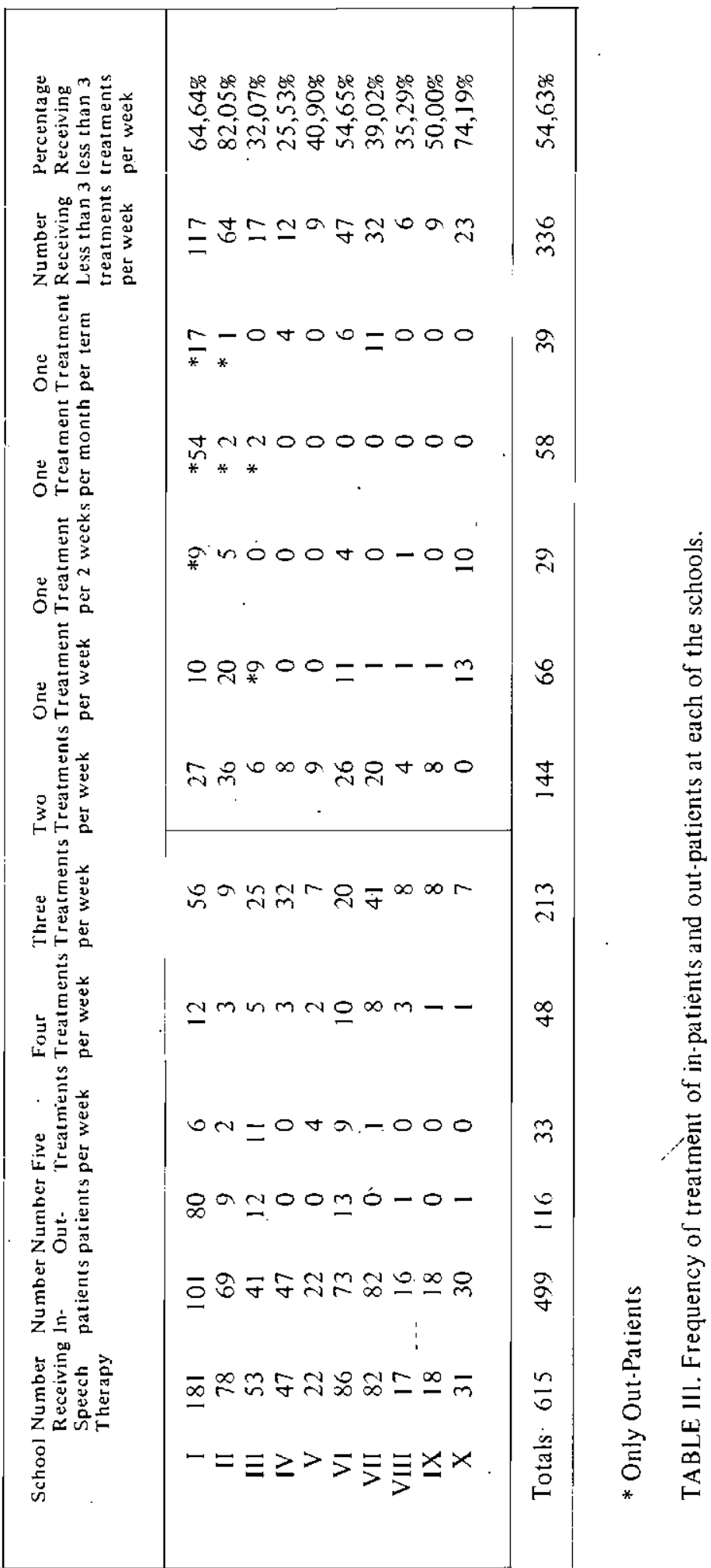




\section{ASSESSMENT OF PATIENTS IN THE TEN CEREBRAL PALSY SCHOOLS}

Nine of the ten schools used a battery of tests to assess speech, hearing and language abilities of their patients. Five of the ten schools did not include details of hearing tests in their replies but almost certainly have some system of hearing screening and/or free field testing and/or formal audiometric assessment. Table IV gives details of the types of tests used.

\begin{tabular}{|c|c|c|c|c|}
\hline School & Hearing & Articulation & Language & $\begin{array}{c}\text { Reading \& Other } \\
\text { Tests }\end{array}$ \\
\hline 1 & $\begin{array}{l}\text { Frec fijeld hearing } \\
\text { tests } \\
\text { Filtered Music } \\
\text { Hearing tests } \\
\text { Pure Tone Audio- } \\
\text { metry } \\
\text { Speech Audio- } \\
\text { metry } \\
\text { Wépman Auditory } \\
\text { Perception } \\
\text { Goldman Fristoe } \\
\text { - Woodcock Audi- } \\
\text { tory Perception } \\
\text { Test } \\
\text { Royal National } \\
\text { lnstitute for the } \\
\text { Deaf Picture } \\
\text { Screening Test } \\
\text { of Hearing }\end{array}$ & $\begin{array}{l}\text { Phonetic } \\
\text { lnventory } \\
\text { Afrikaans } \\
\text { \& English } \\
\text { Renfrew } \\
\text { Articula- } \\
\text { tion } \\
\text { Attain- } \\
\text { ment } \\
\text { Test }\end{array}$ & $\begin{array}{l}\text { Illinois Test of Psycho- } \\
\text { linguistic Abilities } \\
\text { Peabody Picture Vo- } \\
\text { cabulary Test } \\
\text { Northwestern Syntax } \\
\text { Screening I'est } \\
\text { RLLL Scale Assessing } \\
\text { Language Skills in } \\
\text { lnfancy } \\
\text { Houston Test for Lan- } \\
\text { guage Development } \\
\text { Reynell Developmental } \\
\text { Language Scales } \\
\text { Renfrew Word Finding } \\
\text { Vocabulary Scale } \\
\text { Renfrew-Floyd Action } \\
\text { Picture Test } \\
\text { Vocabulary Test for } \\
\text { Young Children. } \\
\text { (Modified from Wat ts) } \\
\text { Renfrew Bus Story } \\
\text { Eisenson Examining } \\
\text { for Aphasia \& Re- } \\
\text { lated Disturbances } \\
\text { Sk Aar Aphasia Scale }\end{array}$ & $\begin{array}{l}\text { Detailed Exami- } \\
\text { nation of Speech } \\
\text { Mechanism, } \\
\text { Breathing, Basic } \\
\text { Functions \& } \\
\text { Phonation. }\end{array}$ \\
\hline $1 I$ & $\begin{array}{l}\text { Free field } \\
\text { hearing tests } \\
\text { Pitch pipes }\end{array}$ & $\begin{array}{l}\text { Goldman } \\
\text { Fristoe } \\
\text { Articula- } \\
\text { tion Test } \\
. \\
\text {, }\end{array}$ & $\begin{array}{l}\text { 1llinois Test of Psycho- } \\
\text { linguistic Abilities } \\
\text { Peabody Picture Vo- } \\
\text { cabulary Test } \\
\text { Basic Concept } \\
\text { lnventory } \\
\text { McDonald, Chance } \\
\text { Language Evaluation } \\
\text { Schuell A phasia }\end{array}$ & $\begin{array}{l}\text { Gates Reading } \\
\text { Readiness } \\
\text { Neales Analysis } \\
\text { Detailed Exami- } \\
\text { nation of Speech } \\
\text { Mechanism, } \\
\text { Breathing, Basic } \\
\text { Functions \& } \\
\text { Phonation }\end{array}$ \\
\hline 111 & $\begin{array}{l}\text { Wepman Audi- } \\
\text { tory Perception } \\
\text { Stycar Test of } \\
\text { Hearing }\end{array}$ & $\begin{array}{l}\text { Renfrew } \\
\text { Articula- } \\
\text { tion } \\
\text { Attain- } \\
\text { ment } \\
\text { Test }\end{array}$ & $\begin{array}{l}\text { Illino is Test of Psycho- } \\
\text { linguistic Abilities } \\
\text { Reynell Developmental } \\
\text { Lang. Scales } \\
\text { Renfrew-Floyd Action } \\
\text { Picture Test } \\
\text { Vocabulary Test for } \\
\text { Young Children } \\
\text { Renfrew Bus Story } \\
\text { Renfrew Word Finding } \\
\text { Vocab. Scale } \\
\text { Northwestern Syntax }\end{array}$ & $\begin{array}{l}\text { U.C.T. Scholastic } \\
\text { Test } \\
\text { Detailed Exami- } \\
\text { nation of Speech } \\
\text { Mechanism, } \\
\text { Breathing, Basic } \\
\text { Functions \& } \\
\text { Phonation }\end{array}$ \\
\hline
\end{tabular}

Table IV continued 


\begin{tabular}{|c|c|c|c|c|}
\hline School & Hearing & Articulation & La nguage & $\begin{array}{c}\text { Reading \& Other } \\
\text { Tests }\end{array}$ \\
\hline & - & & $\begin{array}{l}\text { Screening Test } \\
\text { Eisenson Examining } \\
\text { for Aphasia and Re- } \\
\text { lated Disturbances } \\
\text { Abbreviated Schuell } \\
\text { Aphasia Test } \\
\text { Myklebust } \\
\text { Peabody Picture Vo- } \\
\text { cabulary Test } \\
\text { Hutton-Currie Semi } \\
\text { Diagnostic Test }\end{array}$ & ' \\
\hline IV & $\begin{array}{l}\text { Free field Hearing } \\
\text { Tests } \\
\text { Pitch Pipes } \\
\text { Pure Tone Audio- } \\
\text { metry } \\
\text { Specch Audio- } \\
\text { metry }\end{array}$ & $\begin{array}{l}\text { Phonetic } \\
\text { Inventory }\end{array}$ & $\begin{array}{l}\text { lllinois Test of Psycho- } \\
\text { lingu ist ic Abilities }\end{array}$ & \\
\hline V & $\begin{array}{l}\text { Wepman Audi- } \\
\text { tory Perception } \\
\text { Test }\end{array}$ & & $\begin{array}{l}\text { Pejbody Picture Vo- } \\
\text { cab. Test } \\
\text { Illinois Test of Psycho- } \\
\text { linguistic Abilities }\end{array}$ & \\
\hline VI & $\begin{array}{l}\text { Informal Hearing } \\
\text { Tests } \\
\text { Wepman Auditory } \\
\text { Perception Test }\end{array}$ & $\begin{array}{l}\text { Phonetic } \\
\text { Inventory } \\
\text { Afrikaanse } \\
\text { Artikulasie } \\
\text { Ondersoek }\end{array}$ & $\begin{array}{l}\text { Illinois Test of Psycho- } \\
\text { linguistic Abilities } \\
\text { Peabody Picture Vo- } \\
\text { cabulary Test } \\
\text { Verbal Language De- } \\
\text { velopment Scale } \\
\text { Basic Concept Inven- } \\
\text { tory } \\
\text { Pre-School Language } \\
\text { Development Scale } \\
\text { Teachers Auditory \& } \\
\text { Language Kit }\end{array}$ & $\begin{array}{l}\text { Detailed Exami- } \\
\text { nation of Speech } \\
\text { Mechanism. } \\
\text { Breathing, Basic } \\
\text { Functions \& } \\
\text { Phonation }\end{array}$ \\
\hline VIl & & & $\begin{array}{l}\text { Illinois Test of Psycho- } \\
\text { linguistic Abilities }\end{array}$ & \\
\hline VIII & $\begin{array}{l}\text { Audiometric } \\
\text { Tests }\end{array}$ & $\begin{array}{l}\text { Articula- } \\
\text { tion } \\
\text { Tests } \\
\end{array}$ & Aphasia Tests & . \\
\hline IX & $\begin{array}{l}\text { Goldman } \\
\text { Fristoe } \\
\text { Woodcock } \\
\text { Auditory } \\
\text { Discrimi- } \\
\text { nation }\end{array}$ & $\begin{array}{l}\text { Phonetic } \\
\text { Inventory }\end{array}$ & $\begin{array}{l}\text { Peabody Picture Vo- } \\
\text { cabulary Test } \\
\text { lllinois Test of Psycho- } \\
\text { linguistic Abilities } \\
\text {. }\end{array}$ & $\begin{array}{l}\text { National Bureau } \\
\text { of Educational } \\
\text { \& Social Research } \\
\text { Reading \& Lan- } \\
\text { guage Tests }\end{array}$ \\
\hline $\mathbf{X}$ & v & $\begin{array}{l}\text { Afrikaanse } \\
\text { Artikulasie } \\
\text { Ondersoek }\end{array}$ & $\begin{array}{l}\text { Peabody Picture Vo- } \\
\text { cabulary Test } \\
\text { Illinois Test of Psycho- } \\
\text { linguistic Abilities } \\
\text { Renfrew Language } \\
\text { Scales } \\
\text { Analysis of Speech } \\
\text { Samples of Children }\end{array}$ & $\begin{array}{l}\text { Neales Analysis } \\
\text { of Reading ability }\end{array}$ \\
\hline
\end{tabular}

TABLE IV. Tests used to diagnose Hearing, Articulation, Languagé and Reading in Cerebral Palsy Schools. 
Reference to Table IV indicates the increasing need felt by speech therapists working at cerebral palsy schools to assess their patients as objectively, scientifically and comprehensively as possible. The multifaceted problems presented by patients at a cerebral palsy school are of a very complex nature and without utilizing objective testing procedures one could easily underestimate the severity of a language disorder and/or auditory perception problem while one deals with the inhibition of pathological reflex patterns and facilitation of more normal movements and vice-versa. No single patient is given all the tests, but it is important for the speech therapist to have a wide enough battery of tests to adequately assess all aspects of speech and language. Filtered music hearing testing has been successfully used as a hearing screening technique at School I for the past year. The use of this method enables one to test the hearing of very young and/or retarded and/or hyperactive and/or unco-operative children ${ }^{13}$.

THE VALUE OF JOINT ASSESSMENT OF PATIENTS BY PHYSIOTHERAPIST, OCCUPATIONAL THERAPIST AND SPEECH THERAPIST

Speech therapists working at eight of the ten schools in this survey felt there was real merit in joint assessment of the patients. This is particularly valuable when dealing with the severely handicapped cerebral palsied patient. In the writer's opinion it is one of the best methods of 'in-service training' for therapists and teaches the speech therapist to see her patient as a 'whole' - the essential basis of all the modern techniques of treatment. ${ }^{2}, 10,11,12$

\section{CASE CONFERENCES}

Regular case conferences are held at seven of the ten schools at varying intervals ranging from every six months to every twenty-four months depending on the enrolment at the various schools. Speech therapists in all these schools found the regular case conference a most valuable opportunity for an interchange of ideas about the patient. Problems and difficulties being experienced by one member of the team can be discussed and a combined programme devised to overcome or reduce them. Since the majority of our patients attend the Cerebral Palsy. Schools in South Africa from infancy to late adolescence, we have to live with our failures as well as our successes and it is at the case conference that one sees the integration of the various therapeutic, educational, psychological and social services. As the children mature, their needs change and the emphasis often alters from intensive therapy and formal education' to reduced 'maintenance therapy' and pre-vocational training. The value of the case conference is enhanced if all members of the team know in advance which patients are to be discussed each week, so that they can adequately prepare formal reports including the most recent test results in each department. As assessment should ideally be an 'on-going process' the case conference provides the ideal opportunity to obtain the latest infurmation on the patient from every aspect. This in turn leads to a deeper understanding and appreciation of the patient's problems and difficulties. 


\section{THE USE OF COMMUNICATION BOARDS OR OTHER NON-VERBAI. SYSTEMS OF COMMUNICATION}

This question was included because it is felt that therapists are becoming more realistic. As our experience in this field increases we appreciate that some severely handicapped cerebral palsied patients will never communicate 'easily' on a verbal level and the effort of vocalization and oral communication frequently triggers off such severe spasm or such fluctuations of muscle tone that the patient is rendered completely 'speechless' and very frustrated. By providing an alternate non-verbal means of communication early in the therapy programme we can break this vicious circle and reduce the pressure for verbalization and frustration at not being able to indicate simple everyday wants and needs. McDonald and Schult $z^{6}$ lucidly explain how the early use of communication boards for severely handicapped children, facilitates the development of inner language and the desire to communicate. Hagen, Porter and Brink ${ }^{4}$ reported on the use of a non-verbal electro-mechanical communication device for retarded children with cerebral palsy. Five of the ten schools in the present survey were using or had used a non-verbal communication system. Details will be found in Table V.

\begin{tabular}{|c|c|}
\hline School & Type of Non-Verbal Communication System Used \\
\hline I & $\begin{array}{l}\text { Picture, Picture and Word, Words only, mounted on cardboard or hard- } \\
\text { board covered in transparent plastic. Patient uses head, arm or foot to } \\
\text { point and indicate needs and can formulate sentences. }\end{array}$ \\
\hline II & Magnetic Picture Card on Wheel Chair \\
\hline III & $\begin{array}{l}\text { Previously tried communication board. Now experimenting with Paget's } \\
\text { gesture language system. }\end{array}$ \\
\hline IV & Typing used as an alternate mode of communication. \\
\hline VI & $\begin{array}{l}\text { Picture-Block Board; Movable picture cardboard on "Counting Frame" } \\
\text { principle attached to wheel chair. }\end{array}$ \\
\hline
\end{tabular}

TABLE V. Description of Non-Verbal Communication Systems used in Cereural Palsy Schools.

\section{TRAINING IN HANDLING THE NEUROLOGICALLY IMPAIRED PATIENT}

Work with the neurologically impaired patient is highly specialized and one of the questions asked the therapists was whether they had received special training in this field on (a) an under-graduate level (b) post-graduate level. Their replies are analysed in Table VI.

At the present time the only post-graduate course available in South Africa is the Diploma for Therapists in Special Education (Cerebral Palsied) at the 
University of South Africa. This course does not include actual principles or techniques of treatment. Five of the twenty-six speech therapists in the present survey had completed a Bobath Course in the Neurophysiological treatment of Cerebral Palsy either in London or when Dr and Mrs Bobath visited South Africa or with a 'Bobath trained' teacher. Two therapists had attended Professor Margaret Rood's course on sensory stimulation techniques. The need for a theoretical and practical course on a post-graduate level for therapists dealing with neurologically handicapped patients is becoming ever more urgent. It should include a detailed study of normal development from birth to three years of age and all the neurophysiological techniques of treatment.

The final question of the survey requested the speech therapists to list the topics they would like to discuss if it were possible for speech therapists working at cerebral palsy schools to meet. The forty topics listed appear in the Appendix.

\section{CONCLUSION}

(1) The far-sighted policy of the Department of National Education in allowing pre-nursery school children and young babies to recejve treatment on an out-patient basis at the cerebral palsy schools in South Africa is highly commendable. This policy has led to a decrease in the numbers of severely handicapped, immobile older children because starting treatment at a really young age has many advantages. Some of these are:

(a) the prevention of contractures and deformities or reduction in severity of contractures and deformities.

(b) the inhibition of pathological reflex patterns and facilitation of normal postural reactions and movement sequences enable the children to be more mobile and independent which in turn widens their environment and favourably influences language development.

(c) the prevention of the development of poor patterns of behaviour, learning and attitudes by correct 'early' handling and supportive counselling of parents of young patients.

(d) achieving maximum mental growth and development. Elizabeth Köng states:

On the whole the results have been most encouraging. Furthermore, it is striking that there are fewer mentally retarded children among the cases of cerebral palsy treated early. We believe that their normal motor experience has given these children a chance to develop their normal potentials, whereas the children treated later lack this experience and do not have the same chance to develop normally, so that, unless they are of superior intelligence, they are likely to attain only a subnormal performance. In cases where treatment has not been started until the second year of life the results have not been so satisfactory. ${ }^{5}$

(2) The question of the placement of children in the minimal brain dysfunction and aphasic categories in Cerebral Palsy Schools will have to be considered. There is no doubt that these children benefit from the educational programme and therapies but if their numbers continue to increase, 


\begin{tabular}{|c|c|c|c|}
\hline School & $\begin{array}{l}\text { Number of } \\
\text { Speech } \\
\text { Therapists }\end{array}$ & $\begin{array}{l}\text { Number received under- } \\
\text { graduate training in } \\
\text { C.P. }\end{array}$ & $\begin{array}{l}\text { Number + Details of Post } \\
\text { Graduate Training }\end{array}$ \\
\hline I & 6 & 2 & $\begin{array}{l}2 \text { Bobath, i Rood, } \\
3 \text { Diploma in Special } \\
\text { Education (University } \\
\text { of South Africa) }\end{array}$ \\
\hline II & 3 & 3 & 0 \\
\hline III & 3 & 2 & $\begin{array}{l}1 \text { Bobath, } 1 \text { Rood, } \\
1 \text { M.A. Psychology }\end{array}$ \\
\hline IV & 3 & 1 & $\begin{array}{l}1 \text { Diploma in Special } \\
\text { Education (Cerebral Palsy) }\end{array}$ \\
\hline V & 1 & 1 & 0 \\
\hline VI & 3 & 1 & $\begin{array}{l}1 \text { Bobath + Diploma in } \\
\text { Special Ed (Hearing) } \\
1 \text { Diploma in Special } \\
\text { Education (Cerebral Palsy) }\end{array}$ \\
\hline VII & 4 & 2 & $\begin{array}{l}1 \text { Bobath, } 3 \text { Diploma in } \\
\text { Special Education } \\
\text { (Cerebral Palsy) }\end{array}$ \\
\hline VIII & 1 & 1 & 0 \\
\hline IX & 1 & 1 & 0 \\
\hline$X$ & 1 & ] & 0 \\
\hline Totals & 26 & $\begin{array}{l}15 \text { Therapists } \\
\text { received } 1-2 \text {. } \\
\text { months under- } \\
\text { graduate } \\
\text { training }\end{array}$ & $\begin{array}{l}5 \text { Therapists Bobath trained } \\
2 \text { Shortcourse in Rood } \\
\text { Method; } \\
8 \text { Therapists D.S.E. Cere- } \\
\text { bral Palsy; } \\
1 \text { Therapist D.S.E. Hearing. }\end{array}$ \\
\hline
\end{tabular}

TABLE VI. Details of Numbers of Speech Therapists at each of the ten, schools who had received under-and/or post-graduate training in Cerebral Palsy schools.

provision of separate facilities for them will have to be made. One of the ten schools in the present survey already has $54,78 \%$ of its total enrolment in the minimal brain dysfunction group. The child with a serious language impairment, associated behavioural anomalies, perseveration, disinhibition, short attention span, and a poor memory needs more than 
two or three weekly sessions of speech therapy. He or she needs an organized, 'structured' nursery school or pre-grade programme and daily speech and occupational therapy to overcome his learning, perception and language disabilities as rapidly as possible. If these children are excluded from Cerebral Palsy Schools an alternate programme of schooling and treatment will have to be evolved for them. Although they are difficult to handle especially when very young, they are among our most rewarding cases and our regret is that video-taped progress records have not been kept. If treatment of these children is started early many of them can go to normal schools in Standard I or II.

(3) Merely comparing the ratio of speech therapists to the number of children receiving speech therapy at any given school can lead to a false impression because the frequency of treatment is excluded. Success in this work depends very largely on the intensity and frequency of treatment, repetition and reinforcement being the keys. The numbers of speech therapy posts at cerebral palsy schools should be increased so that:

(a) all children who require speech therapy will receive sufficient treatment

(b) there is time for "in-service" training of new staff, lectures, case demonstrations, joint 'team' assessments, case conferences and student training.

The original formula for the appointment of speech therapists at cerebral palsy schools was drawn up many years ago when these schools catered almost exclusively for the 'pure' cerebral palsied child with a visible motor problem. The population of the cerebral palsy schools currently include as many and in one case more children with 'soft neurological' signs who have a higher incidence of language disorders and problems in conceptualization. If we compare the percentage of language disorders in the cerebral palsy group to that in the minimal brain dysfunction group it will be seen that in six out of the ten schools the percentage is significantly higher in the minimal brain dysfunction group. This difference is increased further if we add the aphasic group to the minimal brain dysfunction group.

(4) Speech therapists working at cerebral palsy schools should familiarise themselves with the latest tests and should critically evaluate the construction of new tests, their validity, reliability and suitability for South African children so that they select appropriate tests to pin-point the child's problems. An urgent need for Afrikaans translation and standardization of language tests exists.

(5) The general impression gained from the one hundred percent return of questionnaires and the detail in which most therapists completed the questionnaire, is that speech therapists working at cerebral palsy schools find this work both rewarding and challenging. Although we may not see results as quickly as our colleagues in general speech therapy practice, there are many advantages to working as a member of a dynamic team 
where medical consultants assess patients together with therapists. In addition, members of the team are accessible for repeated assessments and discussions and are also receptive to suggestions.

By virtue of our geographic isolation from leading centres in Britain, the United States of America and Europe, our, therapists have not become exponents of one method or technique but are attempting to use an holistic eclectic approach. This freedom of choice of treatment results in a very real sense of responsibility on the part of the therapist. A successful eclectic approach is possible only when the therapist has a sound knowledge of the different techniques, including appreciation of their common denominator and is therefore able to select the most suitable approach to meet the child's needs at a particular time. For this reason provision of post-graduate training in the habilitation of the neurologically impaired patient is becoming a matter of urgency.

\section{ACKNOWLEDGEMENTS}

Most sincere thanks are extended to the Principals and Speech Therapists of the ten Cerebral Palsy schools who so willingly co-operated in completing the questionnaires on which this survey was based.

\section{REFERENCES}

(1) Act No. 4l of 1967 (1968): To provide for the establishment, maintenance, administration and control of, and the rendering of financial aid in respect of schools at which certa in classes of education are provided for conferring upon provincial councils powers in respect of certain classes of education and for matters incidental thereto. Republic of South Africa Govermment Gazette, Extraordinary. Vol. 42, No. 2253, December.

(2) Bobath, B., Bobath, K. (1972): The Neurodevelopmental Approach to Treatment. In Physical Therapy Senvices in the Developmental Disabilities. Ed. Paul Pearson, C.C. Thomas, Springfield, Ill.

(3) Eisenson, J. (1972): A phasia in Children. Harper and Row, N.Y.

(4) Hagen, C., Porter, W., Brink, J. (1973): Non-Verbal Communication: An alternate Mode of Communication for the Child with Severe Cerebral Palsy. J. Speech \& Hearing Dis., 38, 4, 448.

(5) Köng, E. (1966): Very Early Treatment of Cerebral Palsy: Develop. Med. Child Neurol., 8, i98-202.

(6) McDonald, E.T. Schultz, A.R. (1973): Communication Boards for Cerebral Palsied Children. J. Speech \& Hearing Dis., 38, 1, 73.

(7) Murray, C.H. de C. (1973): Report to the Management Committee of the National Cerebral Palsy Division of the National Council for the Care of Cripples in South Africa.

(8) Oosthuizen, I., Pelser, J.W. (1973): The Use of Respirator in the Treatment of Cerebral Palsied Children. Physiotherapy, 29, 2. 
(9) Report of the Committee of Inquiry into the Education of Children with Minimal Brain Dysfunction. (No. 72/1969), Government Printer, Pretoria.

(10) Rood, M. (1969): The Use of Sensory Receptors to Activate, Facilitate and inhibit motor response, autonomic and somatic changes in developmental sequence. Unpublished Notes, University of Southern California and Instructional Course, South Africa.

(11) Vojta, V. (1973): Early Treatment of Children at Risk for Cerebral Palsy. Analysis of end results. Monatsschrift für Kinderheilkunde, 121, 271.

(12) Voss, D.E. (1972): Proprioceptive Neuromuscular Facilitation: The P.N.F. Method. Chapter 5 in Physical Therapy in the Developmental Disabilities; Pearson, P. Ed., C. C. Thomas, Springfield, 111.

(13) Waldman, H.L., Cocroft, C.L., Ludi, B. (1974): Filtered Music: A Hearing Test for Young Children. S A Medical Journal, 48, 1772.

\section{APPENDIX}

TOPICS FOR DISCUSSION SUGGESTED BY SPEECH THERAPISTS AT THE CEREBRAL PALSY SCHOOLS

(1) The basis for selecting cases for Speech Therapy at Cerebral Palsy Schools

(2) When should Speech Therapy be terminated?

(3) The frequency of Speech therapy especially for aphasic patients

(4) Improved programming and methods of presentation and work for children with Congenital Auditory Imperception

(5) Views and methods employed by therapists with language cases

(6) Later incidence of and type of language problems in children who initially had delayed speech

(7) Similarities and Differences in symptomatology and treatment of Receptive Aphasia and the Hard of Hearing Child

(8) The Concept of Childhood Aphasia

(9) Techniques for Activating a paralyzed velum in cases of upper motor neurone lesions

(10) How to improve breathing for the cerebral palsied child

(11) The Diagnosis of Aphasia in the Cerebral Palsied Child

(12) Intellectual Capacity or Level and Speech Therapy. Should Speech Therapy be provided for children with low I.Q. levels?

(13) Positioning and techniques to facilitate mouth movements and techniques of Inhibition of Pathological Reflexes 
(14) Drooling

(15) Specific Hearing Tests

(16) Devising and Instituting home programmes

(17) Handling the Infant Cerebral Palsied Child and his Mother

(18) Ideas on running parent counselling groups

(19) The role of the social worker in the Cerebral Palsy School

(20) Use of non-verbal communication in cerebral palsy.

(21) The speech therapist's role in remedial reading \& spelling training of brain injured children with poor language. Should we treat dyslexics in Cerebral Palsy Schools?

(22) Diagnost ic Procedures

(23) Treatment of the Athetoid Child

(24) Standardization of language and auditory discrimination tests on South African Clildren

(25) Translation and standardization of language and other tests into Afrikaans

(26) Tests and training programmes to improve Afrikaans language problems , e.g. generative grammar

(27) Feeding the Cerebral Palsied Child

(28) Orientation of treatment of severe Cerebral Palsy cases who will never talk

(29) Motivating the Cerebral Palsied Child and motivating parents to develop independence

(30) Is under-graduate training in Cerebral Palsy satisfactory?

(31) Language therapy vs. Speech Therapy - Which one should enjoy preference?

(32) Recent research in Speech Therapy Techniques for the Cerebral Palsied child

(33) How professional are we?

(34) Group opinion on our medical orientation

(35) Exchange of ideas on therapy approaches with the Cerebral Palsied child

(36) Discussion on newest developments in the Cerebral Palsied field - medical and therapeutic.

(37) Minimal Cerebral Dysfunction in the Cerebral Palsy Schools - Evaluation and Handling

(38) Compiling and carrying out an integrated therapy and educational programme

(39) Record keeping, test results, doctors reports etc.

(40) Experimental Work - Execution and Results 


\title{
AUDIOMETRIC WEBER AND RINNE TESTS AS COMPARED TO PURE-TONE THRESHOLDS
}

\author{
THOMPSON, ALISON K., B.A. (SP. \& H. TH.) (WITWATERSRAND) \\ Speech Therapy Department, General Hospital, \\ Johannesburg
}

\begin{abstract}
SUMMARY
Results of the audiometric Weber and Rinne tests were compared to pure tone thresholds in 185 Bantu patients. The frequency of $1000 \mathrm{~Hz}$ was selected as being most suitable for Weber and Rinne testing. The Weber was found to be of limited diagnostic value even with unilateral conductive losses whilst the Rinne displays a fair degree of efficiency and is of value as a routine supplement to audiometric threshold tests.
\end{abstract}

\section{OPSOMMING}

Resultate van die oudiometriese Weber en Rinne toetse is met suiwertoon drempels vergelyk. 185-Bantoe pasiënte is as proefpersone gebruik. Die frekwensie van $1000 \mathrm{hz}$ is as die geskikste vir die Weber en Rinne toetse gereken. Die Weber is, selfs met eensydige geleidings verlies, van beperk te diagnostiese waarde gevind, terwyl die Rinne 'n redelike graad van doeltreffendheid getoon het en aanvullend by die oudiometriese drempel toet se gebruik kan word.

At the hearing clinic at Baragwanath Hospital, Johannesburg, routine audiometric Weber and Rinne tests were fairly frequently found to be inconsistent with pure tone thresholds. In the present study, a large number of pure tone audiograms were compared with audiometric Rinne and Weber results.

In recent years, very little has appeared in the literature concerning the Weber and Rinne tests. That which has appeared deals almost exclusively with testing by means of tuning forks. Most authors stress the need to include the Weber and Rinne in a battery of tuning fork tests including the Schwabach and Gellé tests. ${ }^{1 \cdot 3,6}, 8,11,12$ Reliability of these tests has been questioned by these workers but they are nevertheless considered to be useful in supplementing audiometric results.

Testing by means of the audiometric bone vibrator has certain advantages over testing by means of tuning forks. ${ }^{2,8,13}$ The bone vibrator maintains its intensity output at any desired level, whereas the tuning fork fades rapidly in intensity, especially in the high frequencies. ${ }^{11}$ In addition, the bone vibrator permits a standard presentation which is independent of the ear of the operator. ${ }^{5,13}$

\section{MATERIALS AND METHODS}

Hearing assessments of 185 South African Bantu of both sexes with an age range of 12 to 75 years were analysed. These were taken randomly from the 